\title{
Basa Language
}

National Cancer Institute

\section{Source}

National Cancer Institute. Basa Language. NCI Thesaurus. Code C153852.

A cluster of Kainji languages spoken in scattered areas across Nigeria. 